\title{
Penerapan Extreme Programming Untuk Mengakomodir Perubahan Kebutuhan Pengguna Dalam Pembuatan Aplikasi Persediaan
}

\begin{tabular}{|c|c|}
\hline \multicolumn{2}{|c|}{ Ria Ulandari $^{1}$, Nurfia Oktaviani Syamsiah ${ }^{2}$, Reza Maulana ${ }^{3}$} \\
\hline Info Artikel & ABSTRACT \\
\hline $\begin{array}{ll}\text { Diterima Juli 10, } 2021 \\
\text { Revisi } & \text { Agustus 10, 2021 } \\
\text { Terbit } & \text { September 10, } 2021\end{array}$ & $\begin{array}{l}\text { Inventory is very important for a company, including trading companies. Good } \\
\text { inventory management is one of the things to maintain company liquidity. } \\
\text { Utilization of inventory information systems is a change that should be done } \\
\text { so that company goals are achieved in a shorter time and with minimal costs. } \\
\text { Making an information system for a company whose business has been } \\
\text { running stably requires a special method so that the system that will be used }\end{array}$ \\
\hline $\begin{array}{l}\text { Keywords: } \\
\text { Extreme Programming } \\
\text { Inventory Management } \\
\text { Inventory } \\
\text { Information System } \\
\text { Agile }\end{array}$ & $\begin{array}{l}\text { For this reason, the involvement of system users from the beginning to the end } \\
\text { of the system creation stage is very necessary, and the flexibility of changing } \\
\text { Programing (XP) answers these expectations, because of its flexibility that is } \\
\text { able to deliver a system according to user needs, which often change in the } \\
\text { span of system development. The Inventory Application at the Al Akram } \\
\text { Division is a case study that was raised in this research. By utilizing XP, the } \\
\text { researcher succeeded in making the Inventory application (AkaDia) with the } \\
\text { achievement of user acceptance test results reaching 94\%. }\end{array}$ \\
\hline
\end{tabular}

\section{Identitas Penulis:}

Ria Ulandari ${ }^{1}$, Nurfia Oktaviani Syamsiah ${ }^{2}$, Reza Maulana ${ }^{3}$

Universitas Bina Sarana Informatika, Program Studi Sistem Informasi Akuntansi Kampus Pontianak, Jalan Abdurrahman Saleh No.18 A Pontianak,

Email: riaulandari240499@gmail.com¹, nurfia.nos@bsi.ac.id², reza.rza@bsi.ac.id ${ }^{3}$

\section{PENDAHULUAN}

Manajemen persediaan mengacu pada semua kegiatan yang terlibat dalam mengembangkan dan mengelola jumlah persediaan bahan baku, bahan setengah jadi dan barang jadi sehingga persediaan yang memadai dapat tersedia dengan total biaya yang rendah [6]. Persediaan adalah salah satu aset, tetapi dengan tingkat likuiditas yang rendah. Sehingga jika suatu perusahaan memiliki asset yang sebagian besarnya adalah persediaan maka perusahaan sangat memungkinkan untuk mengalami kesulitan dalam memenuhi kewajiban jangka pendeknya disebabkan tidak dapat diubah dengan mudah ke dalam bentuk uang tunai [4]. Pengelolaan persediaan pun menjadi tulang punggung bagi setiap perusahaan karena dengan pengelolaan yang baik maka keluaran yang dihasilkan dapat digunakan oleh perusahaan untuk menjadi dasar dalam upaya mendapatkan produk dengan harga yang potensial [11].

Terdapat berbagai macam cara mengelola persediaan, mulai dari cara yang sederhana yang memanfaatkan catatan kertas hingga penggunaan sistem yang lebih kompleks seperti aplikasi pengolah angka, aplikasi sistem informasi berbasis desktop, web, atau berbasis jaringan. Setiap pilihan cara tersebut memiliki kelebihan dan menyesuaikan dengan kebutuhan organisasi yang berbeda. Menurut [12] manfaat yang didapatkan ketika menerapkan sistem informasi persediaan adalah dalam hal penghematan biaya, meningkatkan efisiensi, keamanan dan keselamatan data dan informasi. Sedangkan menurut [2] manfaat yang didapat adalah peningkatan operasi manajemen, pengurangan biaya dan total waktu pelaksanaan, pengurangan waktu respons untuk kepentingan pelanggan dan peningkatan efisiensi kinerja sistem. Penerapan sistem informasi persediaan sangat penting dalam memberikan informasi, menghindari penumpukan persediaan, menghindari penurunan transaksi dan meningkatkan pengendalian internal atas persediaan [9].

Yayasan Pondok Digital pada divisi Al-Akram kegiatan utama usahanya adalah bidang perdagangan produk speaker Al Qur'an. Sampai saat ini sistem pencatatan data persediaan barang yang dilakukan masih memanfaatkan catatan konvensional. Setiap periodenya pegawai akan mengerjakan pendataan barang yang 
mencakup data barang baru datang, barang lama yang masih pantas dipakai, bahkan barang yang rusak dan seharusnya diganti, kemudian data tersebut ketik ulang dan diproses menjadi laporan data persediaan. Proses pengumpulan data seperti ini tidak cukup efektif sebab dibutuhkan ketelitian, dalam pengumpulan data dengan jumlah barang yang tidak sedikit kerap kali menyebabkan terjadinya redundancy data (data ganda) dan dalam proses pengerjaan laporan data persediaan membutuhkan waktu yang lama karena proses yang berulang-ulang. Seperti halnya ketika menyelesaiakan pembuatan laporan data persediaan untuk pendataan barang baru yang akan diletakan pada ruangan yang tersedia, pegawai wajib melakukan pengecekan ulang pada keadaan barang yang tersedia di ruangan dan merevisi laporan persediaan barang tersebut.

Penelitian ini bertujuan untuk membangun sistem informasi persediaan pada divisi Al-Akram Yayasan Pondok Digital Aghnia. Sistem yang akan dikembangkan diharapkan bisa menyampaikan data secara realtime sehingga jika ada barang yang baru masuk serta ada perubahan pada status barang, pengguna dapat langsung mengakses informasi tersebut. Selain itu waktu yang diperlukan dalam pengembangan sistemnya diupayakan sesingkat mungkin agar manfaatnya dapat segera dirasakan oleh pengguna. Di sisi lain, jumlah anggota tim di sisi peneliti pun cukup terbatas, sehingga diperlukan suatu metode yang mampu menjawab kebutuhan tersebut. Sebagian besar pengembang menggunakan metode waterfall, padahal seringkali ditemukan perubahan spesifikasi dari pengguna di pertengahan bahkan dipenghujung penyelesaian proyek yang menyebabkan perubahan pada rancangan dan implementasi sistem [8]. Hal tersebut tentunya berdampak pada keberhasilan pengoperasian sistem, waktu dan biaya yang dikeluarkan saat menyelesaiakan proyek. Hal ini dapat dihindari dengan menggunakan metode pengembangan lainnya, karena pada dasarnya metode pengembangan perangkat lunak relatif banyak yang dapat digunakan untuk mencapai tujuan.

Dalam penelitian ini sesuai dengan harapan pengguna agar sistem dapat segera digunakan dan menyesuaikan dengan jumlah tim proyek maka metode yang digunakan adalah Extreme Programming (XP). XP adalah metodologi pengembangan yang dikembangkan oleh Kent Beck pada tahun 1996 saat mengerjakan proyek penggajian C3. Kemudian pada tahun 1999, Kent Beck menerbitkan bukunya "Extreme Programming Explained" untuk menyajikan bentuk XP yang disempurnakan. XP adalah pendekatan pengembangan perangkat lunak yang sederhana, lebih fleksibel dan dengan tingkat risiko rendah namun memiliki kemampuan untuk mengelola persyaratan kebutuhan yang bahkan tidak jelas ataupun berubah dengan cepat. Oleh karenanya XP dianggap lebih cocok untuk tim pengembang kecil dan menengah [1].

Menurut [5] dengan menggunakan XP, proses yang dilakukan lebih adaptif dan juga sangat fleksibel, memungkinkan pengembangan perangkat lunak untuk mengikuti perubahan yang cepat sesuai dengan kebutuhan bisnis dan persaingan global. Selain itu juga dapat mengurangi biaya administrasi dan overhead, meningkatkan produktivitas staf, dan memenuhi kebutuhan pelanggan. Dengan memanfaatkan XP maka penyelesaian akan lebih cepat dengan risiko minimum dan XP sangat cocok untuk proyek perangkat lunak berukuran kecil [3].

XP paling cocok digunakan untuk pengembangan proyek yang membutuhkan adaptasi cepat terhadap perubahan selama pengembangan aplikasi. Pemilihan sistem yang sesuai dengan kerangka kerja pengembangan akan memiliki dampak yang signifikan terhadap pengembangan perangkat lunak itu sendiri, sehingga tidak ada masalah pada perangkat lunak yang dihasilkan [10].

\section{METODE}

Penelitian ini menggunakan metode penelitian deskriptif. Dimana dengan menggunakan metode ini maka dilakukan penggambaran fenomena yang nyata, realistis, aktual dan terjadi pada saat ini. Cara yang dapat dilakukan adalah dengan membuat deskripsi ataupun gambaran secara sistematis, faktual dan akurat mengenai fakta-fakta, sifat-sifat serta hubungan antar fenomena yang diamati [7].

Metode pengembangan sistem yang digunakan adalah extreme programming $(X P)$ karena berdasarkan kondisi tim pengembang dan hasil diskusi awal dengan pengguna yakni Yayasan Pondok digital Aghnia, maka pemanfaatan $X P$ dianggap lebih tepat. Lima tahapan yang akan dilakukan terlihat pada gambar 1, yakni:

(1) Perencanaan: Ini adalah langkah pertama dalam siklus hidup pengembangan Extreme Programming. Tugas utamanya adalah untuk menetapkan tujuan dari seluruh proyek dan siklus iteratif tertentu. Pada titik ini, tim bertemu dengan pengguna dan bertanya tentang semua aspek yang dibutuhkan dari perangkat lunak yang akandikembangkan. Pengguna merumuskan visi produk dalam bentuk cerita pengguna. Pengembang mengevaluasi dan memprioritaskan dalam bentuk dokumen perencanaan. Untuk kemudian dilanjutkan dalam hal yang lebihnyata.

(2) Merancang: Pada tahap ini, tim harus menentukan karakteristik utama dari sistem yang akan dibangun. Kemudian membuat desain sederhana, karena kesederhanaan adalah salah satu prinsip dasar metodologi XP. 
Pengembang sering kali berbagi tanggung jawab pada tahap desain namun tetap bertanggung jawab atas setiapdesain yang dihasilkan.

(3) Pengkodean: Kata kunci dari XP adalah bahwa kode yang baik harus sederhana, karenanya perbaikan kode program senantiasa dilakukan hingga didapatkan kode yang paling sederhana. Dengan adanya prosedur refactoring memungkinkan untuk menyederhanakan kode atau bagian-bagiannya tanpa mempengaruhi fungsionalitas produk akhir.

(4) Pengujian: prosedur pengujian dilakukan bukan setelah produk akhir atau produk antara dibuat, tetapi saat dilakukan pengkodean.

(5) Product Increment: Pada tahap akhir siklus hidup pengembangan, diupayakan untuk mendapatkan umpan balik dari pengguna yang menjadi satu-satunya pihak berwenang dalam memperkirakan produk final.

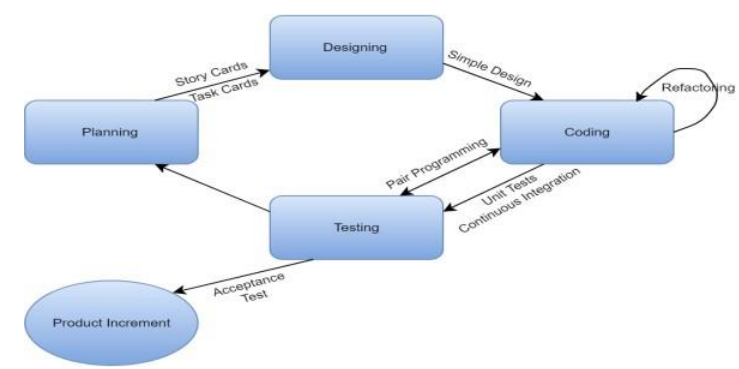

Sumber: (Kumar \& Dwivedi, 2021)

Gambar 1. Siklus Extreme Programming

\section{HASIL}

\subsection{Perencanaan}

Tahap pertama ini dilakukan dengan melakukan diskusi bersama pengguna terkait kebutuhan sistem yang akan digunakan dalam bentuk pemahaman proses bisnis, pendefinisian output aplikasi, fitur-fitur dalam aplikasi, fungsi aplikasi, penentuan waktu dan biaya aplikasi hingga alur pengembangan aplikasi. Pengguna menceritakan kebutuhannya kemudian diterjemahkan oleh pengembang yang salah satunya dapat terlihat dalam bentuk sebuah dokumentasi kebutuhan fungsional pada Tabel 1.

Tabel 1. Daftar Kebutuhan Fungsional

\begin{tabular}{|l|l|l|}
\hline $\begin{array}{c}\text { Kode } \\
\text { Kebutuhan }\end{array}$ & Nama Pengguna & Jenis Kebutuhan Fungsional \\
\hline KF-01 & Admin Gudang 1 & Kelola Data Barang \\
\hline KF-02 & Admin Gudang 1 & Kelola Data Kategori Barang \\
\hline KF-03 & Admin Gudang 1 & Kelola Data Barang Masuk \\
\hline KF-04 & Admin Gudang 2 & Kelola Data Barang Keluar \\
\hline KF-05 & Admin Gudang 2 & Kelola Data Barang Retur \\
\hline KF-06 & PIC Produksi & Kelola Data Pengguna \\
\hline KF-07 & PIC Produksi & Melihat Data Laporan Persediaan \\
\hline
\end{tabular}

Sumber: Hasil Penelitian (2021)

\subsection{Perancangan}

Tahapan kedua dilakukan dengan memanfaatkan UML, dan karena penekanan XP adalah pada desain sistem yang sederhana, waktu yang singkat dan lebih fokus pada pemrograman dan pengujian program maka dengan menggunakan sebagian dari Diagram UML saja sudah cukup untuk merepresentasikan perancangan sistem dalam penelitian ini. Adapun Use Case diagram pada gambar 2 dibuat berdasarkan kebutuhan fungsional yang dihasilkan dari tahap perencanaan. 
Sumber: Hasil Penelitian (2021)

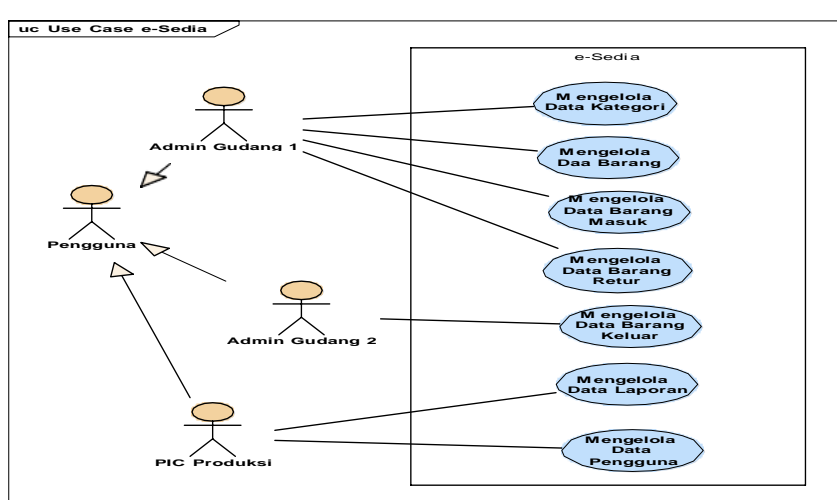

\section{Gambar 2. Use Case Diagram e-Sedia}

Selain menggunakan UML, Proses perancangan ini menggunakan juga Entity Relationship Diagram (ERD) yang dapat terlihat pada gambar 4. Dimana dari gambar tersebut terdapat Sembilan entity dan delapan relasi yang sudah dilengkapi dengan kardinalitasnya masing-masing.

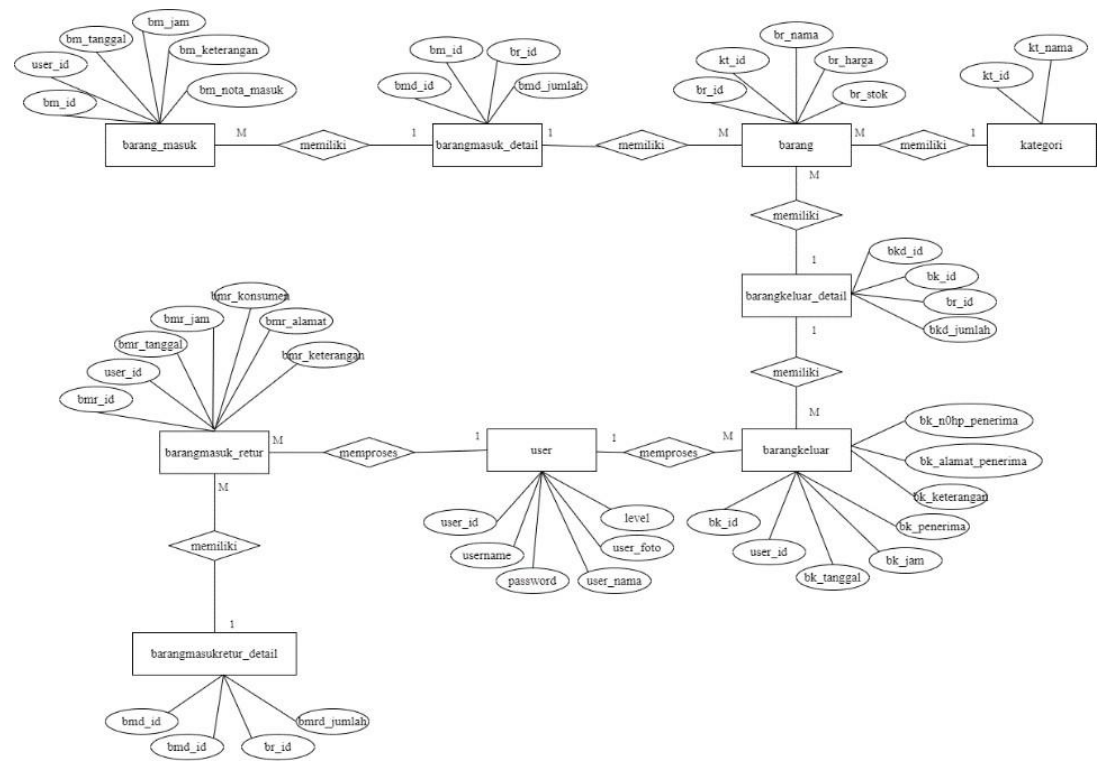

Sumber: Hasil Penelitian (2021)

Gambar 3. Entity Relationship Diagram

Hasil Pemetaan ERD digambarkan lagi menjadi sebuah Logical Record Structure (LRS) yang dapat terlihat di gambar 3 . 
Sumber: Hasil Penelitian (2021)

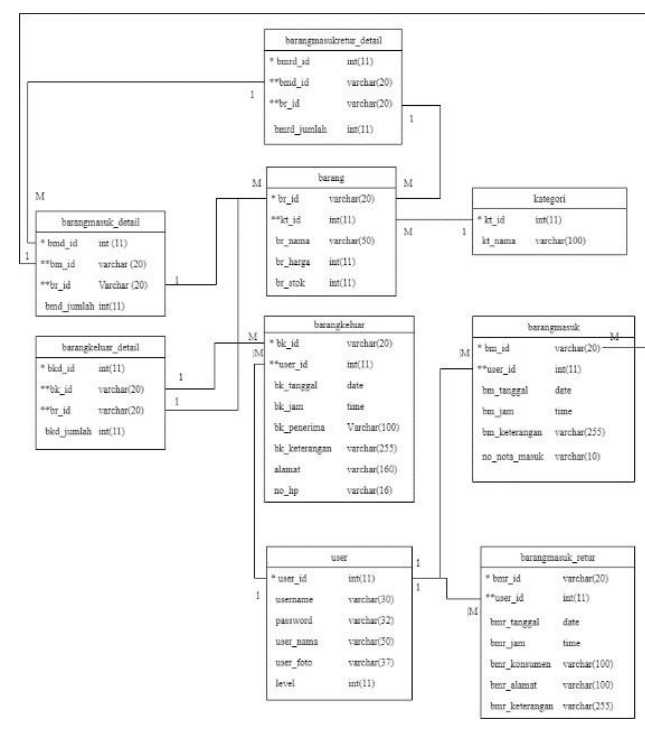

\subsection{Pengkodean}

\section{Gambar 4. Logical Record Structure}

Proses pengkodean dilakukan dengan menggunakan Bahasa pemrogrman PHP disertai juga dengan HTML, CSS dan Java Script. Adapun hasil pengkodean menghasilkan User Interface seperti yang terlihat pada tabel 2.

Tabel 2. Pengkodean di UI

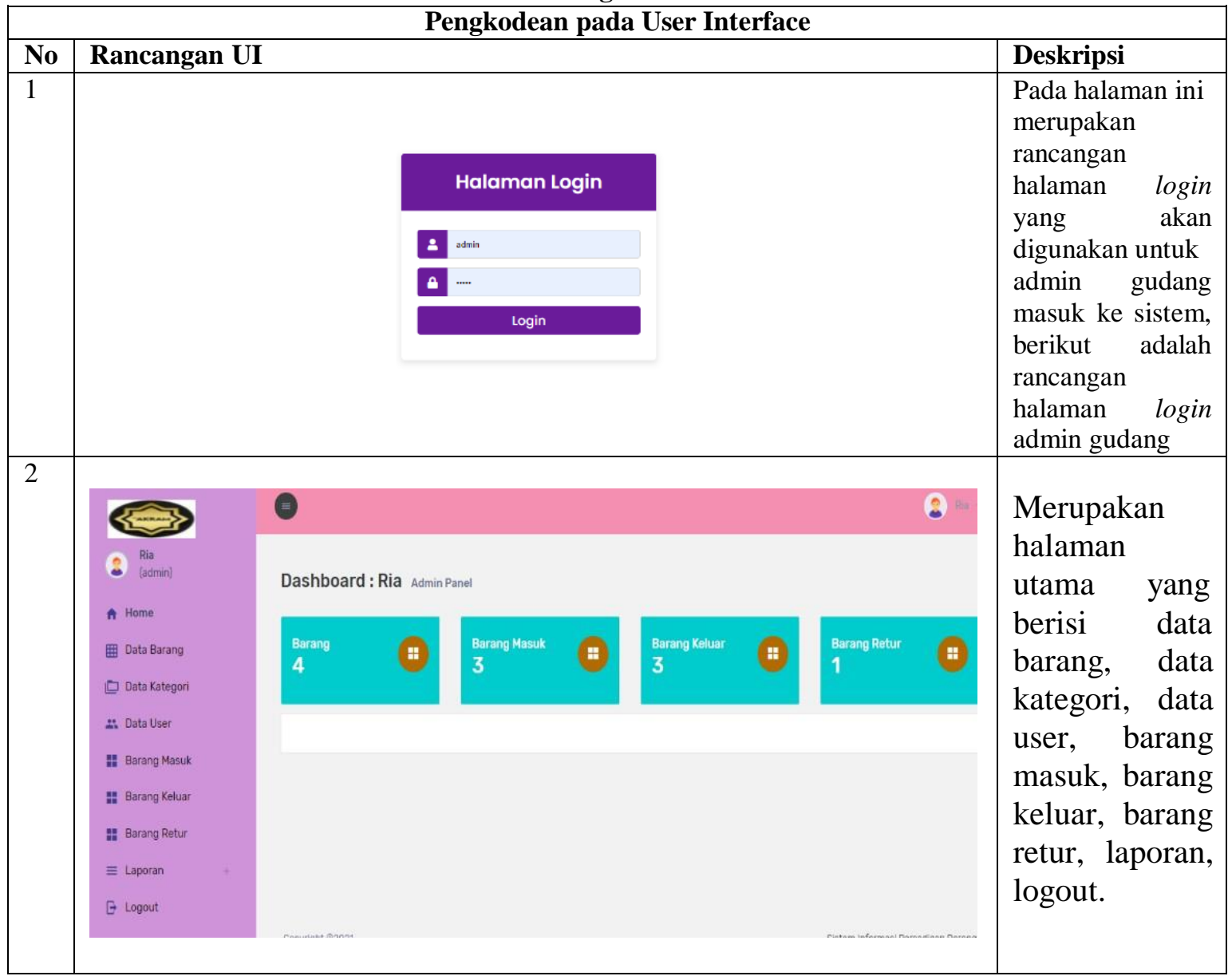


Vol. 02 No. 02, September 2021, pp. 77 85

E-ISSN: 2721-7523

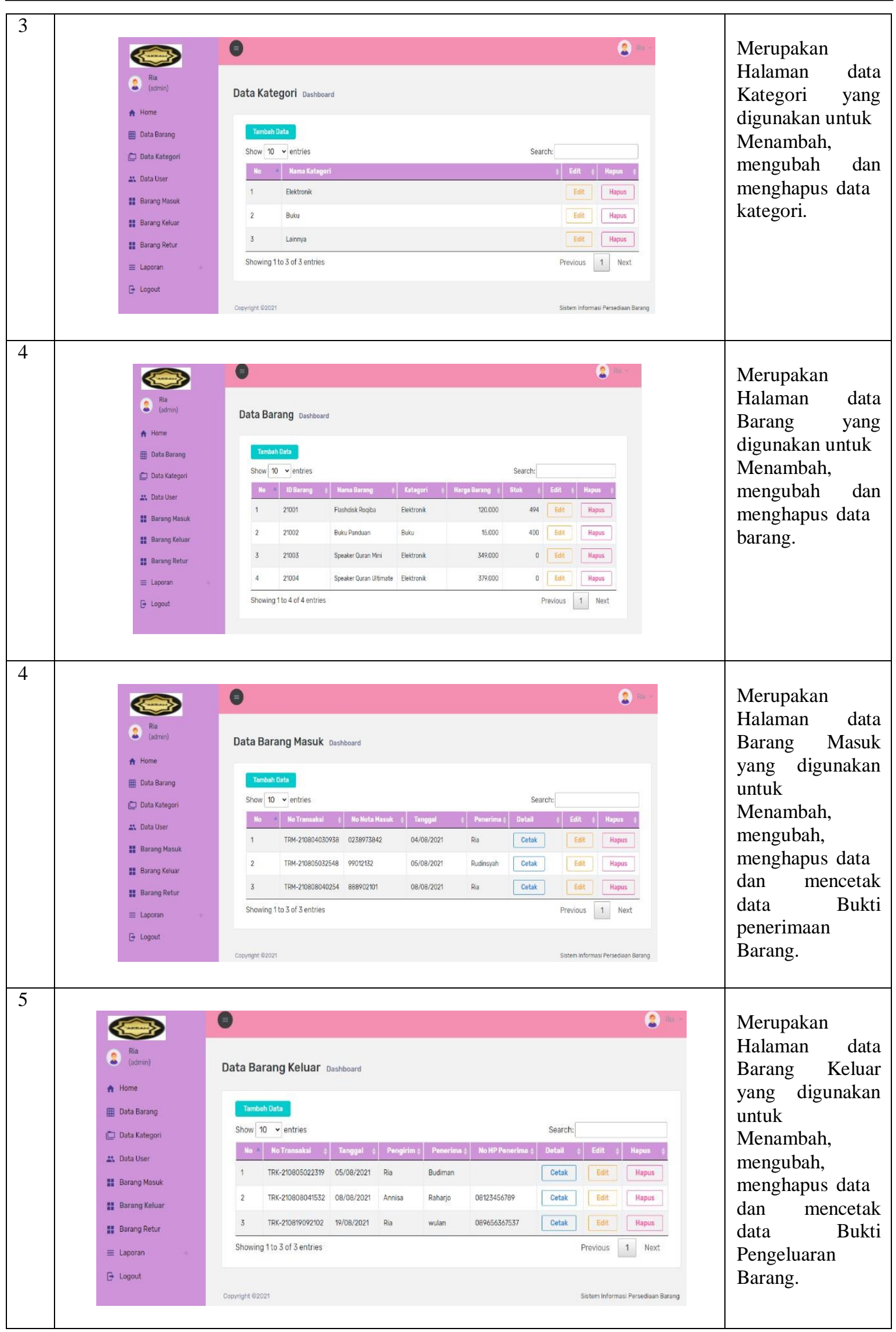




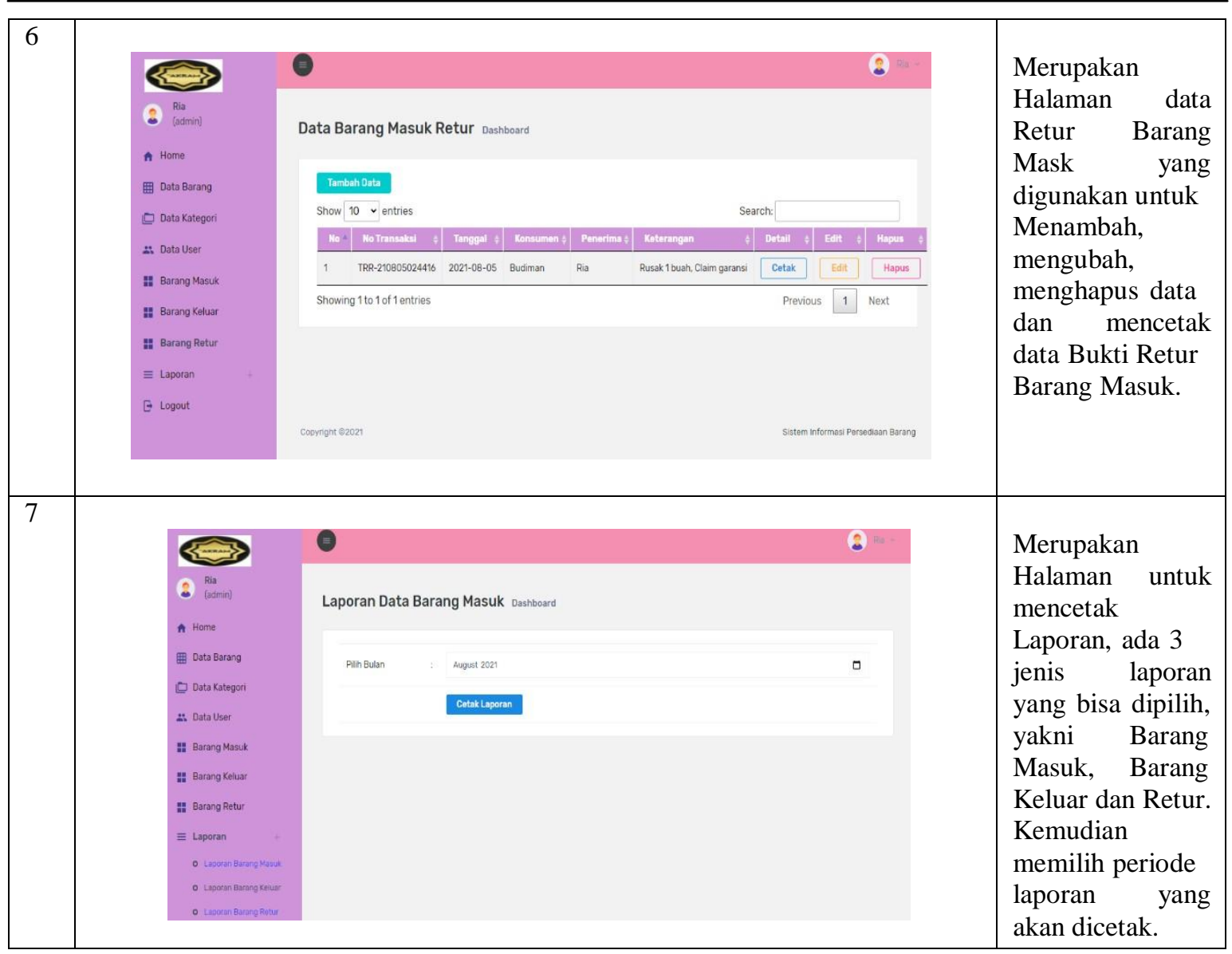

Sumber: Hasil Penelitian (2021)

\subsection{Pengujian}

Pada XP, pengujian menjadi tahapan yang juga krusial. Untuk pengujian white box sudah dilakukan saat proses pembuatan kode program. Selanjutnya pengujian dilakukan dengan metode black box untuk pengujian unit. Pengujian ini dilakukan untuk memastikan bahwa kode bebas dari kesalahan. Adapun hasil pengujian yang telah dilakukan terlihat pada tabel 3 .

Tabel 3. Hasil Pengujian Unit

\begin{tabular}{|l|l|c|c|}
\hline \multirow{2}{*}{ No } & \multicolumn{1}{|c|}{ Fitur yang diuji } & \multicolumn{2}{|c|}{ Sudah sesuai dengan Proses Bisnis } \\
\cline { 3 - 4 } & & Ya & Tidak \\
\hline 1 & Log In (seluruh penguna) & V & \\
\hline 2 & Halaman Utama & V & \\
\hline 3 & Halaman Data Barang & V & \\
\hline 4 & Halaman Data Kategori & V & \\
\hline 5 & Halaman Barang Masuk & V & \\
\hline 6 & Halaman Barang Keluar & V & \\
\hline 7 & Halaman Retur & V & \\
\hline 8 & Halaman Cetak Laporan & V & \\
\hline
\end{tabular}

Sumber: Hasil Penelitian (2021)

Selain dari pengujian yang melibatkan perbaikan kesalahan pengkodean, pengujian penerimaan (Acceptance Test) juga dilakukan. Penerimaan tes memverifikasi persyaratan seperti yang dipahami oleh pengembang dan apakah sudah memenuhi persyaratan dari pengguna ataukah belum. Pengujian ini dilakukan terhadap 3 pengguna yang ada, yakni Admin 1, Admin 2 dan PIC Produksi. Daftar pertanyaan yang diajukan terlihat pada Tabel 4. Sedangkan pembobotan dari setiap jawaban dapat terlihat pada tabel 
Tabel 4. Daftar Pertanyaan untuk Pengguna

\begin{tabular}{|l|l|l|l|l|l|l|l|}
\hline No & \multicolumn{1}{|c|}{ Pertanyaan } & \multicolumn{3}{c|}{ Penilaian } & \multirow{2}{*}{ Jumlah } \\
\cline { 4 - 6 } & & SS & S & N & TS & STS & \\
\hline 1 & $\begin{array}{l}\text { Apakah "AkaDia" diperlukan untuk mengelola } \\
\text { Persediaan? }\end{array}$ & & & & & \\
\hline 2 & Apakah "AkaDia" mudah digunakan? & & & & & & \\
\hline 3 & Apakah user interface dari "AkaDia" menarik? & & & & & & \\
\hline 4 & Apakah "AkaDia" memudahkan pekerjaan Anda? & & & & & \\
\hline 5 & $\begin{array}{l}\text { Apakah penataan dan penyajian informasi pada } \\
\text { "AkaDia" memudahkan untuk membaca dan } \\
\text { mencari informasi persediaan? }\end{array}$ & & & & & \\
\hline
\end{tabular}

Sumber: Hasil Penelitian (2021)

Tabel 5. Bobot Jawaban

\begin{tabular}{|l|l|}
\hline \multicolumn{1}{|c|}{ Jawaban } & Bobot \\
\hline SS : Sangat Setuju & 5 \\
\hline S : Setuju & 4 \\
\hline N : Netral & 3 \\
\hline TS : Tidak Setuju & 2 \\
\hline STS : Sangat Tidak Setuju & 1 \\
\hline
\end{tabular}

Sumber: Hasil Penelitian (2021)

Hasil dari Pengujian terhadap Penerimaan Pengguna dihasilkan persentase sebesar 94\%, yang didapatkandari total akumulasi jumlah nilai dari ketiga responden untuk kelima pertanyaan yang diberikan.

\subsection{Product Increment}

Tahapan yang merupakan tahap akhir ini adalah untuk merilis aplikasi yang telah berhasil dibuat, dan siap digunakan oleh pengguna.

\section{KESIMPULAN}

Extreme Programming (XP) mendorong pemrogram untuk mengikuti standar pengkodean dan bekerja bersama saat melakukan pengkodean. Hal ini terutama dilakukan untuk mencapai hasil yang lebih baik. XP tidak mengikuti pendekatan tradisional dalam pengumpulan dokumen yang lengkap terkait spesifikasi kebutuhan, tetapi lebih kepada kuantitas pendokumentasian kode program. XP memberikan perubahan pengembangan sistem sesuai dengan kebutuhan pengguna setiap saat selama fase pengembangan aplikasi, sehingga kebutuhan pengguna akan aplikasi yang sesuai dengan kebutuhannya dapat diakomodasi. Dengan XP yang setiap langkahnya selalu melibatkan pengguna, programmer, dan tim pengujian maka aplikasi yang dibuat dapat selesai tepat waktu dan sesuai dengan kebutuhan pengguna. Aplikasi yang dibuat dalam penelitian ini merupakan aplikasi persediaan barang dagang (AkaDia) yang telah diuji secara white box maupun blackbox yang mana hasilnya aplikasi sudah tidak memiliki kesalahan (error) dan aplikasi sudah sesuai dengan proses bisnis yang dibutuhkan pengguna. Selain itu juga telah dilakukan Uji Penerimaan Pengguna dengan hasil 94\%. Sehingga dapat dikatakan bahwa aplikasi ini dapat membantu memudahkan pekerjaan penggunanya, mudah dalam pengoperasian serta menarik dari sisi tampilan layarnya.

\section{UCAPAN TERIMA KASIH}

Terima kasih kami ucapkan kepada seluruh pihak terkait atas terlaksananya penelitian ini, terutama kepada Allah swt, serta kepada pihak penerbit yang telah berkenan untuk menerbitkan paper ini.

\section{REFERENSI}

[1] Anwer, F., Aftab, S., \& Muhammad, S. S. (2017). Comparative Analysis of Two Popular Agile Process Models: Extreme Programming and Scrum. March.

[2] Fang, X., \& Chen, H. C. (2021). Using vendor management inventory system for goods inventory management in 
IoT manufacturing. Enterprise Information Systems, 00(00), 1-27.

https://doi.org/10.1080/17517575.2021.1885743

[3] Flora, H., \& Yadav, K. S. (n.d.). Review On Extreme Programming-XP Related papers Review On Extreme Programming-XP.

[4] Hudori, M. (2018). Formulasi Model Safety Stock dan Reorder Point untuk Berbagai Kondisi Persediaan Material. $\begin{array}{lllll}\text { Jurnal Citra Widya } & \text { Edukasi, }\end{array}$ https://journal.cwe.ac.id/index.php/jurnal_citrawidyaedukasi/article/view/109/98

[5] Kumar, M., \& Dwivedi, R. K. (2021). Agile Modeling with Extreme Programming: Values, Principles, and Practices. International Research Journal of Engineering and Technology, 1872-1879. www.irjet.net

[6] Masudin, I., \& Kamara, M. S. (2018). Singaporean Journal of Business Economics, and Management Studies ( SJBEM ) Impact of Inventory Management and Procurement Practices on Organization 's Performance. 6(3), 3239. https://doi.org/10.12816/0044429

[7] Rukajat, A. (2018). Pendekatan Penelitian Kuantitatif. Deep Publishing.

[8] Shrivastava, A., Jaggi, I., Katoch, N., \& Gupta, D. (2021). A Systematic Review on Extreme Programming. https://doi.org/10.1088/1742-6596/1969/1/012046

[9] Siagian, A. O. (2020). Contribution of Inventory Accounting Systems in Improving Inventory Internal Control. 16.

[10] Suryantara, I. G. N., \& Andry, J. F. (2018). Development of Medical Record With Extreme Programming SDLC. International Journal of New Media Technology, 5(1), 47-53. https://doi.org/10.31937/ijnmt.v5i1.706

[11] Tejada, G., Tuliao, E. M., Eroy, N. G., \& Buladaco, M. V. M. (2021). ANALYSIS AND DESIGN OF A SALES AND INVENTORY MANAGEMENT ANALYSIS AND DESIGN OF A SALES AND INVENTORY MANAGEMENT INFORMATION SYSTEM FOR A MOTORCYCLE PARTS AND ACCESSORIES STORE Abstract : July.

[12] Utami, M. C., Sabarkhah, D. R., Fetrina, E., \& Huda, M. Q. (2019). The Use of FIFO Method for Analysing and Designing the Inventory Information System. 2018 6th International Conference on Cyber and IT Service Management, CITSM 2018, Citsm, 1-4. https://doi.org/10.1109/CITSM.2018.8674266 